\title{
Elements of a Theory of Religious-Secular Competition
}

\author{
Jörg Stolz' \\ Pascal Tanner ${ }^{2}$
}

\section{Abstract}

This article presents basic elements of a theory of religious-secular competition on the individual level. The theory claims that individuals in many societies may choose between religious and secular options, creating a situation of competition between religious and secular institutions. The competition between religious and secular suppliers is influenced by three important contextual factors: innovation, regulation, and resources. We give six examples of empirical studies showing that the theory of religious-secular competition explains such contrasting phenomena as the difference in success of religious healing in European and African countries, the diminishing and change of religious socialization in Switzerland, variations in church attendance in U.S. states, variation in the attractiveness of monasteries, the late secularization of Ireland, or the success of megachurches since the 1970s.

Keywords: Religious-secular competition. Secularization. Religious change.

"Instead of praying pilgrims, what we see are singers, gymnasts, firemen, soldiers, year-goers, Sunday defilers in company with modern ladies overflowing hill and valley, chasing in impetuous haste and irrepressible lust, free breath and the pleasures of life".

(THE ANNALS OF PIUS, 1875)

\section{Introduction $^{3}$}

The contrast could not be greater: religious leaders have been reporting for a long time that their religious communities are in tough competition

\footnotetext{
1 Professor de Sociologia da Religião na Universidade de Lausana (Suiça) e presidente da Sociedade Internacional para a Sociologia das Religiões (ISSR/SISR).

2 Doutorando do Fonds national suisse de la recherche scientifique (FNS) e pesquisador do Institut de sciences sociales des religions contemporaines (ISSRC).

3 This article is based on ongoing theoretical work. Previous versions of the theory can be found in Stolz (2009. 2013) and Stolz, Könemann et al. (2016).
} 
not so much with other religious communities, but with secular institutions (MCMULLIN, 2013; SCHULZ, 2006, p. 123). But religious sociological research has so far paid almost no attention to this fact. Pastors, priests, and imams are faced with the increasingly difficult tasks of getting people interested in their offers and developing marketing and branding strategies. But religious sociological research seems blind to this fact, because religion is not a "product" in the views of most researchers.

Remarkably, the three most important sociological theories of religion in contemporary society - secularization theory, individualization theory, and market theory - have so far rarely treated the phenomenon of religious-secular competition. The reasons for this are not difficult to find.

The secularization theory is essentially a macro-theory, which points to major societal modernization processes (differentiation, rationalization, societalization) and claims that these processes are leading to a general decline of religion (POLLACK; ROSTA, 2015; VOAS; CHAVES, 2016; WALLIS; BRUCE, 1995). Because the perspective is on large-scale processes, the theory seems unable to integrate religious-secular competition on a meso-level and individual choices on the micro-level.

The individualization theory argues that modernization does not lead to secularization, but to a change in religious forms (KNOBLAUCH, 2008, 2009; LUCKMANN, 1967). According to this theory, church-based, institutional religiosity is diminishing, but it is replaced by new (and often difficult to recognize) individualized and privatized forms of religiosity. In the well-known text by Luckmann (1967) we can find elements of a description of religioussecular competition. All in all, however, neither he nor the subsequent literature kept track of this issue. This is in part a result of Luckmann's extremely broad functional definition of religion that made secular competition unrecognizable, since it was by definition also called "religious".

It is particularly astonishing that the so-called market theory has not taken religious-secular competition into serious consideration (IANNACCONE, 1998; STARK; FINKE, 2000). It is true that Iannaccone (1988) presented an early model in which individuals can choose between religious and secular goods. But this promising start was overshadowed by the unfortunate assumptions that humans have a stable demand for transcendental goods (such 
as an "eternal life") and that only religious organizations could provide such goods (STARK; IANNACCONE, 1994). This was paramount to excluding the idea of religious-secular competition by definition.

We believe that the phenomenon of religious-secular competition is important and has not yet received the attention it deserves. The goal of this article is to present the basic elements of the theory of religious-secular competition on an individual level. This theory argues that individuals in many societies can choose between religious and secular options, that this possibility leads to competition between religious and secular offers, and that the joint effects of competing organizations and individual choices produce interesting aggregated sociological explananda.

As noted, in this article, we treat only one of two important forms of religious-secular competition, namely competition for individual actions and choices (= type 1 competition). There is, however, a second type: religious secular competition for societal rules and regulations (FOX, 2015; STOLZ et al., 2016). Sometimes this type 2 competition concerns the overall power in a state (e.g. the Iranian revolution); sometimes it concerns specific laws of accommodation of religious groups (e.g. concerning veiling, tax exemption); and sometimes it concerns rules inside collective religious actors, (e.g. how much emphasis the "religious" and "secular" activities should get in a congregational youth camp). The religious-secular competition for rules and regulations must be treated in another article.

In the following, we present the precursors of an approach to religioussecular competition (2) and in the main part we discuss the basic concepts, mechanisms, and predictions of the theory (3). In part (4), we review examples of empirical research on religious-secular competition to date. We conclude in part (5) with a review of the structure of explanation here proposed and a comparison with secularization theory.

\section{Religious-secular competition in the literature}

The phenomenon of religious-secular competition has not always been disregarded. In various disciplines - economics, sociology, marketing science, and history - researchers have formulated approaches that describe religioussecular competition from a different perspective. 
Economy - In economy of religion discourses, religious-secular competition is predominantly treated from an individual perspective. The seminal article of the religious economy approach begins with a model in which households must decide between religious and secular time use (AZZI; EHRENBERG, 1975). In this model, it depends, among other things, on the opportunity costs of religious activity (for example, on the market wage) if and how often individuals go to worship. Laurence Iannaccone, the most important present exponent of the religious economy approach, used this idea to explain the emergence of "churches" and "sects" (IANNACCONE, 1988). However, as mentioned above, Iannaccone and his followers have missed the importance of religious-secular competition for the explanation of a great many other examples. A notable exception is the essay by Gill and Lundsgaarde (2004), in which the authors show that the secular welfare state can become a major competitor of the Christian churches (which also offer welfare services). One of the most telling pieces of evidence showing how important religious-secular competition is from the viewpoint of religious leaders has been presented by Hungerman (2010). He shows that a sample of pastors in the U.S. view the competition of secular institutions as much greater for their churches than the competition from other Christian churches. This finding has since been replicated in a NCLS study in Australia in 2011 (Figure 1). The differences are striking and exist for all types of denominations, mainline or evangelical.

Sociology - In sociology, arguments referring to religious-secular competition have been mainly established with respect to the emergence of new types of professions. Abbott (1988) analysed the religious-secular competition at the level of different professions in various countries (especially the U.S., Great Britain, and France). Abbot starts with the assumption that professions are trying to secure the legitimate treatment of certain problems and to defend this position against competing professional groups. Consequently, they must rely on their own way of diagnosing, making inferences, and treating these problems (ABBOTT, 1988). In their work, clerics must refer to a final value of "salvation, meaning, ultimate questions", which, according to Abbott, has met with decreasing interest in twentieth-century societies. Therefore, clerics tried to bring other societal areas under their influence and within their sphere of competence. Abbott names the areas of social welfare, mass education, and life problems. In all these domains, however, the clerics, after initial successes, were fought by other, secular professional groups, and finally pushed back. For example, the clerics dealing with life problems found themselves first in tough 
competition with neurologists, then with psychologists and psychotherapists. They ultimately lost this battle because they could not present their techniques and treatment methods as scientifically sound. Bourdieu (1987) worked on religious-secular competition in an essay where he also focused on the analysis of occupational groups that compete for the legitimate treatment of lifeproblems. According to Bourdieu, during the twentieth century, the idea of a "soul" that was the uncontested area of expertise for clerics became less and less convincing; the soul-body distinction virtually broke down. Consequently, the "religious field" in its former Gestalt disintegrated and dissolved into a more extensive field of the symbolic treatment of mind and body. Thus, according to Bourdieu, the clerics suddenly had to enter into competition with a large number of professional groups, which also dealt with the spirit and the body, albeit often with non-religious symbols: Psychoanalysts, sexologists, body therapists, teachers of Asian martial arts, coaches, life counsellors etc., who do not promise "salvation" and "eternal life", but healing, well-being, and meaning.



Graphic I - Perception of religious-secular and intra-religious competition by principal church leaders in Australia

Source: own calculations with NCLS principal church leader dataset of 20II. N = 2019; response rate $=75 \%$. See for the methodology of the study Pepper, Sterland and Powell (2015). 
Marketing - In contrast to economics and sociology, the marketing literature treats religious-secular competition not with regard to professional groups but with regard to organizations such as churches, religious communities and movements, and how religious organizations strategically make use of marketing and branding (MOTTNER, 2007). In doing so, they usually assume a state of religious-secular competition as if this were selfevident. For example, Mara Einstein (2008, p. 9) concludes in her widely known publication that: "We shouldn't be surprised then that religion whether in the form of a film or a church - is being marketed in the current commercialized culture. In order to be heard above the noise of the rest of society, religion, too, must participate in order to survive".

Why does marketing science assume religious-secular competition as a matter of course, while other disciplines struggle to recognize this phenomenon? The reason is that marketing approaches start with human needs. Einstein asks which needs may be covered by religious organizations and how these needs may be satisfied more efficiently. Asking these types of questions means recognizing a multitude of other institutions that can also satisfy such needs (such as security, meaning, integration, education) and thus compete with religious organizations.

History - Finally, some historians have pointed out the importance of religious and secular competition in Western European countries in the twentieth century. Hugh McLeod (2007), Urs Altermatt (2009), and Yves Lambert (2007 [1985]) have shown that new leisure activities such as dancing, football, travel, or shopping as well as car driving, television, pop music, and sex were becoming important competitors for religious practices and religious lifestyles. For example, Altermatt (ALTERMATT, 2009, p. 275) reports the following about the competition for Sunday activities in Switzerland:

Already shortly after World War II, the Christian Churches were concerned with the question of Sunday observance, issuing a joint letter on the topic of "Sunday" in 1950. The debate was no longer about how factory work or work in the fields violated Sunday observance. Rather, it pointed to the competition between Sunday sanctification and Leisure society, because the emerging consumer society radically changed the Sunday behaviour of the Catholics.

In particular, according to Altermatt (2009), rising income and new technology (such as television, cars) made these new ways of life possible. 
The new lifestyle had to be established against the strong opposition of the churches and the traditionally-minded part of society. As the anti-hedonist norms progressively disintegrated, the leisure-society could unfold and spread to every corner of the country. Altermatt also notes, however, that churches responded not merely by resisting. They also tried to accept and control the new leisure activities (in moderate forms) by organizing them themselves and rethinking them in religious terms. Since the beginning of the twentieth century, churches have thus offered travel opportunities, leisure activities, sports clubs, and so on. But as the leisure market evolved and specialization increased, the churches lost whatever control they had had on the leisure market and became just another leisure provider among many.

To recap, while the three most prominent theories of religion in modernity take little or no notice of religious-secular competition, concepts and evidence about religious-secular competition are widespread in various disciplines. What seems to be missing in the literature is a general theoretical synthesis on religious-secular competition that brings the various insights into one coherent scheme. This is what we aim to achieve in this paper.

\section{Outline of a theory of religious-secular competition on the individual level}

\section{I The basic idea}

The structure of the theory is shown in Figure 1. The basic idea is that macro conditions (innovations, regulations, resource distributions) influence the religious and secular suppliers (1) who compete for the time, energy, attention, and money of families and individuals (2) (3). Innovations, regulations and resource distributions also influence families and individuals directly (4) (5). Family socialization influences the preferences and beliefs of individuals (6). And the aggregated actions of suppliers (7) and individuals (8) create the explananda or aggregated effects. 


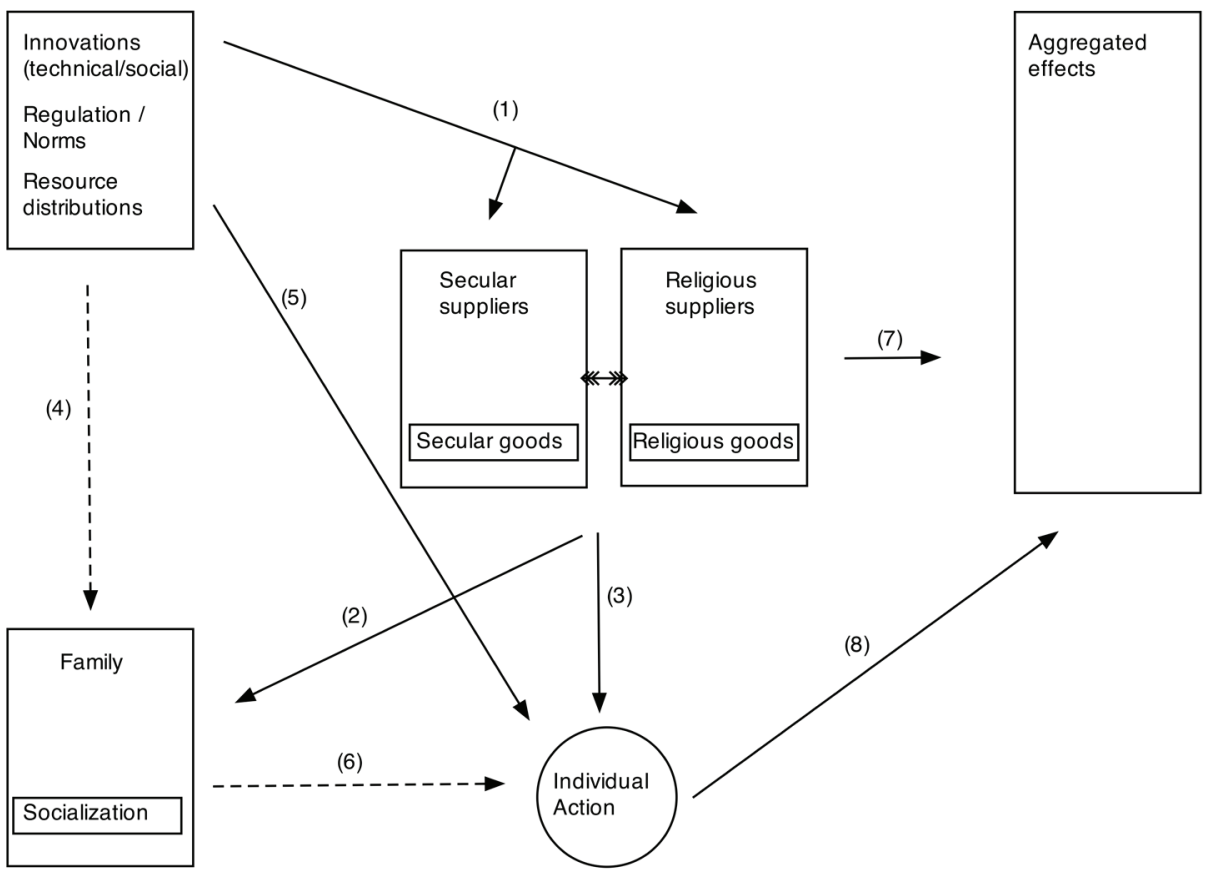

Figure I - The structure of the theory of religious-secular competition on an individual level

Source: Own composition

The theory of religious-secular competition stands in the tradition of socalled explanatory or analytical sociology (BOUDON, 1974; ESSER, 1999; HEDSTRÖM, 2005). According to this approach, to explain means to work out the exact mechanisms that create a specific phenomenon. As can be seen in figure 1, the theory distinguishes three levels of social reality: a macro-level of societal conditions, a meso-level of organizational and group competition, and a micro-level of family socialization and individual action. Note that the phenomena to be explained by the theory are located both on the meso- as well as on the macro-level and can refer to both aggregated individual and organizational behaviour. To create explanations, one has to adapt this general model by specifying the concrete nature of the different elements (e.g. societal conditions, types of competitors). By doing so, one transforms the theoretical 
meta-model into a theory of the "middle range" (MERTON, 1968). Below we will present examples of such "middle range" theories (part 4).

Clearly, a theory of religious-secular competition only makes sense if we can separate religious from secular groups. We think that for most sociological questions, a mainstream definition of religion and religious group or suppliers is quite sufficient. Thus, we define religion as a cultural symbol system that responds to problems of meaning and contingency by pointing to a transcendent reality; and we define a religious group as a collective actor that has a central reference to a religion - e.g. representing a religious ideology, offering religious goods, or performing religious collective activities - compare to Pollack (1995); Stolz et al. (2016, p. 23f.). It is important to note that with this definition we see religion basically as a means of explaining and treating a problematic world in a symbolic and transcendence-related way. War and peace, good health and illness, life and death, happiness and sorrow, good or bad weather, - all of this can be linked to the will of gods and thus be treated with ritual - even if the exact mechanisms that cause these phenomena are not (yet?) clearly understood. This is also why innovations tend to undermine religion.

While such a definition suffices to delimitate the religious sphere, it does not follow that everything excluded from the definition (the secular) counts automatically as a secular competitor of religious groups. We address the question of identifying the secular competitors below (3.3).

Note that the delimitation of religious and secular suppliers is itself a matter of competition (the type 2 competition mentioned above), influenced by innovations, regulations, and resource distributions. For example, religious and secular collective actors may fight concerning the question of how strongly state schools act as socialization agencies of specific religions.

\subsection{Context effects: innovations, regulations, resource distributions}

Religious-secular competition can be influenced, according to our theory, by three central factors: innovations, regulations, and resource distributions. These factors are themselves complex, contain many processes and must be specified for concrete research. In the following, some general possibilities are outlined and illustrated by examples. 


\subsection{Innovations}

In line with recent economic and historical theories, our theory places a particularly strong emphasis on innovations (CARON, 2001; MÜLLER; VEYRASSAT, 2001). An innovation may be defined in a very broad way as a "new idea, device, or method" that is linked to the idea of improvement or superiority and therefore permits (or at least promises) to better solve a problem. Innovations may influence the state of religious-secular competition by changing the productivity of one or both of the competitors, or by changing the competition game in general with its goals, rules, and representations. Let us look at some examples.

The discovery of the theory of evolution by Charles Darwin changed the entire religious-secular field of competition, since it opened up for the first time the opportunity to explain the origin of the human species in a purely secular way (DARWIN, 1985 [1859]; PORTIER; VEUILLE; WILLAIME, 2011). The results of historical and critical Bible studies, initiated, for example, by Julius Wellhausen's work on the Old Testament and by David Friedrich Strauss' work on the life of Jesus, profoundly changed the religious-secular field of competition within Protestantism and within Western societies as a whole (RÖMER, 2004; SCHWEITZER, 1966; THEISSEN, 2001). The welfare state, which was invented in the second half of the nineteenth century and greatly expanded in many Western countries in the 1950s, led to a previously unknown degree of individual security, a security that was independent of religious communities and ideologies (KAUFMANN, 1997). The invention of modern professions in the nineteenth century, which replaced the guilds, led to the triumph of scientifically legitimated expert knowledge. The new careers that thereby emerged - in particular, journalists, doctors, social workers and psychotherapists - became key competitors to religious leaders (the clergy) (ABBOTT, 1988; CONZE; KOCKA, 1985; RUSSELL, 1980).

While it is true that innovations will very often be detrimental to religion and further secularization, the religious sphere may also innovate and come up with inventions that may give certain religious groups an important edge. Thus, the Pentecostal practices of the early twentieth century proved to be an incredibly successful innovation worldwide. Other examples are televangelism, megachurches, Salafism, or Western-type Yoga. Indeed, all major religious 
and spiritual movements can be viewed as successful innovations that have successfully gained ground in a fierce competition.

A few general points concerning innovations and their impact on religious-secular competition should be noted:

1) Many innovations are rationalizing in the sense that they improve the way a certain goal can be reached. They are often based on a better understanding of some sort of problem. Hence, innovations often have a secularizing nature. If a problem (e.g. how to explain earthquakes) had hitherto not been understood and was explained by the will of god, an innovative scientific explanation (e.g. as seismic waves caused by geological faults) will often be considered more satisfactory and will replace the religious solution. However, innovations are not always rationalizing and do not necessarily lead to the withdrawal of issues and responsibilities from the religious domain (e.g. the invention of social media created the emergence of fake news). Rather, they change the conditions of the competition in which different actors find themselves.

2) While some innovations affect religious-secular competition directly, many (e.g. the discovery of bacteria and viruses or the laws of gravity) act indirectly by modifying - at first barely perceptibly - the consciousness of people. They affect, to echo Berger (1990 [1967]), people's general "plausibility structure".

3) Sometimes, innovations lead to increased differentiation of the social structure. For example, the invention of the car led to a differentiated car industry; the invention of the computer has led to a differentiated computer science, various computer-related professions, and a whole computer industry. However, innovations may also lead to "dedifferentiation", as when cars and trains replaced the horse, thus drastically reducing the variety of horse-related occupations (RAULFF, 2015) or when the mass media wiped out the great diversity of itinerant entertainers (ABBOTT, 1988, p. 28).

4) Many innovations have mixed effects and may help or hinder religious and secular collective actors at different stages of the social process. The spectacular progress of biomedicine, for example, is rather bad news for many religious healing practices. But it gave churches the possibility to 
build their own hospitals that could then compete with secular hospitals. Inside religiously led hospitals, a new religious-secular competition could arise between religious and secular leaders and between religious and secular personnel (nuns vs. nurses). Or, to give another example, the invention and use of the printing press allowed Reformation ideas to be disseminated with an unprecedented speed and efficiency (EDWARDS, 1994); on the other hand, it later allowed disseminating all kinds of secular ideologies as well.

5) While the focus on innovations has undeniable links to modernization theory, it has the advantage of making us notice the various possibly conflicting effects of specific innovations for religious and secular competitors. We can then better grasp both secularizing and resacralizing effects of innovations. In our view, the theory of religious-secular competition is thus able to integrate secularization theory - but can equally formulate conditions in which resacralization phenomena are to be expected. Secularizing innovations may be counteracted not only by religious innovations, but also by two other important factor highlighted by the theory of religious-secular competition: regulations and resources. This said, it remains true that the overall trend expected by religious-secular competition theory (just as in modernization theory) is secularization. Religion, a symbolic treatment of phenomena that are not (yet) scientifically understood, is in the long run crowded out by scientific/technical understanding and control.

\subsubsection{Regulation}

In all societies, the competition between religious and secular collective actors is strongly regulated. There is a great variety of regulations (FOX, 2015). Some regulations are positive (e.g. giving public recognition, financing to certain providers); others are negative (e.g. hindering the practice of a religion, prohibiting the construction of a religious building). Some regulations are put into place by the state (e.g. laws); others emerge from the day-to-day functioning of society (e.g. norms, habits). Some regulations control organizations and groups (e.g. tax exemption, establishment); others focus on individuals (e.g. veiling prohibitions, blasphemy laws).

Such regulations obviously change the way the competition game between religious and secular suppliers is played out and strongly influences 
possible outcomes. To give just three examples: in Switzerland, in many cantons the state officially recognizes certain religions that have a certain number of rights (very important: levying church tax), but also obligations. These regulations give established religious actors an important, especially financial, advantage compared with other (religious or secular) competitors (STOLZ; CHAVES, 2017). The German Democratic Republic was known for its explicit anti-religious regulations; it abolished religious education, dissolved Christian youth movements and introduced scientific atheism as a state doctrine (FROESE; PFAFF, 2005). An example from the U.S. are the "charitable choice" policies receiving a large importance with executive orders signed by George Bush Jr. in 2002 (CHAVES, 1999). This legislation allowed the state to financially support not only secular but also religious providers of social welfare facilities.

\subsubsection{Resources}

The competition between religious and secular suppliers is, finally, dependent on the distribution of resources both on the level of the religious and secular groups on the supply side and the families and individuals on the demand side. In a very general way, we can distinguish economic, social, and cultural resources (compare to the forms of "capital" in Bourdieu, 1980, p. $191 \mathrm{ff}$. .). For example, religious and secular suppliers depend on money and land (economic resources), number of members, clients, customers, social contacts (social resources), as well as their public image and legitimacy (cultural resources). Changing these resources of either competitor will normally affect the outcome of the religious-secular competition. If churches lose members (loss of social resources), this means fewer donations (loss of economic resources) and in the end a smaller offer of religious goods that can compete with secular goods. But resource distributions are equally important on the side of families and individuals who equally dispose of economic resources (e.g. money, land), social resources (e.g. friendship-ties, network-ties, familyties), and cultural resources (e.g. knowledge, education, language proficiency). These resources will both enable actors to engage in certain actions and limit the range of options (what economists call the feasible set). For example, if the average income of individuals rises substantially, permitting them to consume secular biomedicine or secular leisure options (e.g. long distance tourism) 
that were formerly outside their budget, this may lead to a drop in religious activities. On the other hand, for individuals with small incomes, it makes no difference whether a new opera house is built - since these individuals could not afford tickets anyway.

To sum up, innovations and changes in regulations and resources influence how the religious-secular competition is played out in specific sociohistoric contexts. This leads us to the question of identifying the religious and secular providers.

\subsection{Religious and secular providers and their goods}

Religious providers can be individuals, social groups, and organizations, which refer to a religion and produce religious goods. Protestant communities, Hindu temples, Muslim centres, or Zen meditation course leaders are all religious providers in this sense. Secular providers are all those individuals, social groups, and organizations whose secular goods compete with religious goods. But who are the secular competitors of religious providers? We can find an answer when we understand that religious suppliers compete with secular suppliers concerning specific human needs (Table 1). A religious group may offer spiritual healing - but there may be secular biomedical offers that can treat the same illness more specifically. A religious supplier may offer a religious ideology that explains much about the world - but education, science, and secular ideologies may do likewise. Individuals with depression can demand the religious good "pastoral care" - but they can also choose the secular competitor "psychotherapy". The need for social contacts can be satisfied by the religious good "active membership in a religious community" - but there exist secular competitors, such as sports clubs, neighbourhood networks etc. Whereas religious groups are competing with a whole range of secular institutions, religiously run institutions (choirs, hospitals, schools, aidorganizations) are normally competing more particularly with their secular counterparts. When distinguishing religious and secular suppliers and their goods, one inevitably encounters borderline or hybrid cases that are difficult to classify - well-known examples are Alcoholics Anonymous, Star wars religion, Rave culture, or extreme cases of pop and brand fandom (STOLZ; USUNIER, 2013, p. 12). These cases notwithstanding, the distinction is in most cases quite straightforward and does not present many difficulties. Note 
that the competitors of specific religious actors and their goods are not set once and for all, but may vary in different contexts, change over time, and depend on the regulation of religious-secular competition. Specific studies must always ascertain just what competitors exist in a determined situation and what their specific goods are.

Table I - Religious groups and institutions and their secular competitors

\begin{tabular}{ll}
\hline Religious group and its.... & Secular competitor \\
\hline$\ldots$ salvation promises & $\begin{array}{l}\text { Welfare state, insurances, biomedicine, high } \\
\text { standard of living }\end{array}$ \\
$\ldots$ religious ideology & (Higher) education, science, secular ideologies \\
$\ldots$ collective activities, social capital & Secular leisure time activities, social capital \\
$\ldots$ life-cycle rituals & Work-holiday cycle, secular rituals \\
$\ldots$ pastoral care by its leaders & Psychotherapists, life coaches \\
\hline Specific Institutions run by religious groups & Secular competitors \\
\hline choir, schools, hospitals, aid organizations & choir, schools, hospitals, aid organizations \\
\hline
\end{tabular}

Source: Own composition

\subsection{Attributes of religious and secular goods}

It is important to realize that religious goods differ from secular goods in at least four ways. Only the first point is a necessary difference; the other points mention differences that are a matter of degree and may or may not be given in specific instances.

First, religious goods are transcendence-related; they are linked to some sort of god, spirit, or transcendent power that allows pursuing goals of either an immanent or a transcendent nature (e.g. health, success, eternal life, illumination). From a social scientific point of view, these transcendent entities are socially constructed - just like norms, ideas, or language. Secular competitors lack this element of transcendence by definition. As is well known, secular providers often try to give their goods additional meaning; a car will not just let you drive but make you seem attractive; a coffee cannot just be consumed but will show that you are a person with taste and class. Sometimes this marketing strategy goes so far as to make us speak of quasi religions for certain goods (e.g. Jeep, Star Trek, Mac, Harley Davidson). However, in most 
cases of such marketing, these additional meanings will not go so far as to postulate superhuman beings or forces that individuals may get in contact with; in short: they do not drift into the realm of transcendence.

Second, religious goods are always ideology-related. They are goods, so to speak, only because of the religious ideology (symbol-system, religion) encompassing them. Being freed of original sin is a salvation good only if the individual accepts a Christian framework; losing one's ego seems attractive and sensible only to a person subscribing to Buddhist ideology. Such ideologies must be learnt to be effective in interpreting the world. This explains why religious socialization is so important for religion: without it, the religious goods become shallow and fade away. Secular goods, on the other hand, are often much less dependent on ideology in order to be useful for the individual. A powerful drug against pain will have some effect even if we do not believe in its effectiveness, and one can drive a car or use computers without being a member of a fan-group of these products. Of course, the social world in general is socially constructed in the sense that we have to believe collectively in our institutions and cultural objects to make society continue to exist (SEARLE, 1995). This is true for religious and secular suppliers and goods. Our argument here is only that religious goods reliy in comparison to a very large extent on shared ideology.

Third, religious goods are group-related. It is social groups that act as plausibility structures for these types of goods. It is because other group members also believe in the goods that the goods exist. The goods in their turn always carry a group-related meaning with them. Thus, an ecclesiastical marriage integrates the participants into an ecclesiastical community or denomination, while a secular ritual marriage refers only to the married individuals themselves. While there are equally secular goods that are grouprelated, many secular goods can do without a group as a plausibility structure.

Fourth, religious goods are often not sold on markets. While the terminology of goods suggests otherwise, it must be understood that religious goods are only in some cases subjected to market-type exchange. Religious services are almost never paying; pastoral care is normally free. As everything in life, these activities must somehow be paid for, but this is mostly done by donations or general membership taxes and not for the specific religious service. Of course, 
examples of explicit market logic in the religious domain do also exist (e.g. Catholic sale of indulgences, religious consumer goods in shops) just as well as there are secular goods that are not exchanged on markets. But again, in comparison, secular goods can be found more often on markets.

To sum up this point: religious goods are transcendence-related; they work only in the framework of ideologies and groups, and they are often produced and distributed within specific groups, but outside of markets. These points can also be described with the conceptual pair "diffuse-specific" (PARSONS, 1991 [1951]). Religious goods are diffuse in the sense that several references are always given; a transcendence-, ideology-, and group- reference is always attached to the good. In contrast, the goods of the secular competitors are normally more specific. They lack a reference to transcendence, and they often do not presuppose membership in a group or belief in a specific ideology.

\subsection{Religious and secular socialization}

In our model, families must socialize their children and choose how much religious and/or secular socialization they should give their children. These choices are influenced by the religious/secular offer, that is, how attractive catechism, youth groups, religious services for kids are in comparison to other, secular education opportunities (sports clubs, leisure time activities). They are also influenced by the resources of the families (if, say, secular or religious schools are affordable). The choices are very often strongly influenced by norms, dictated either by the state or by society in general (what is deemed a normal socialization). There is again a very strong competition concerning these norms where religious and secular collective actors try to change the rules of the game (type 2 competition). Families are assumed to try to make restricted rational choices, that is, they try to have good reasons for their choice of religious/secular options in accord with the options, norms, and resources.

Religious socialization is an important point since, as we have seen, religious goods are strongly dependent on shared ideology and groups as plausibility structures. The ideology and the feeling of being a group member are mostly transmitted during an individual's youth, through families and the societal surroundings. Empirical research suggests that in Western countries of the last decades, cohorts basically retain the level of religiosity acquired in 
their youth (VOAS; CHAVES, 2016). From the viewpoint of the theory of religious-secular competition, this means that the religiosity of every cohort is determined mainly through the state of religious-secular competition of society during its youth.

\subsection{Religious and secular action}

From the perspective of the theory of religious-secular competition, individuals usually act in a (restrictedly) rational manner (BOUDON, 2003). They usually have "good reasons" for their behaviour, choosing between religious-secular options based on their preferences and beliefs as well as their resources.

Strong rationality assumptions have been rightly criticized, but it is only with some assumption of rationality or intentionality that we can create theories in which individuals or groups - at least in the long run and in the aggregate - react in a foreseeable way to changes in context, opportunities, rules, or representations.

Based on this assumption of (restricted) rationality, we can then formulate hypotheses, such as: If the secular options increase or are made more attractive, then individuals will increasingly choose these secular options - and less often the competing religious options (or vice versa). If a new rule is introduced making veiling obligatory for women, and if sanctions are put in place, women will put on the veil more often.

Our rationality assumption is rather weak. Specifically, we assume that (1) individuals use a restricted or simplified rationality, which is much easier to use, but much less perfect than that of the homo economicus; it also includes a series of "anomalies" (seen from the homo economicus model (ESSER, 1999; SIMON, 1983); (2) many reactions to changes in context factors can better be seen in the aggregate than in the individual, since individuals are often influenced by a variety of idiosyncratic causes (HECHTER, 1987, p. 31); (3) many reactions can be seen only in the long run since there are many factors that slow the reaction down. Most importantly, norms of behaviour in groups as well as individual psychology may stay rather stable once individuals have been socialized in their teen years. 
To make one additional point: Of course, seen from the individual viewpoint, secular and religious options often are not mutually exclusive. One can remain a member of the church, but actively engage in football or Rotary. Yet, our theory claims that, in the long run and in the aggregate, changes in innovations, regulations, and resources will create substitution effects and often favour either the religious or the secular side.

\section{Examples}

In the following, we will give six examples of empirical studies that can be framed as applying the theory of religious-secular competition.

\section{I Religious healing in post-industrial and agrarian societies}

A first example is spiritual healing, which is competing with biomedical treatment in both Western European and African countries. In both contexts, a diffuse system of holistic healing, which treats the body, the soul, and the circumstances all at once is opposed to an extremely specific biomedical system (DOW, 1986; KIEFER, 2007). In the African part of the world, however, spiritual healing (partly traditionally anchored, partly Pentecostally oriented) has a huge influx, while in Western European countries it is not widespread at all (ANYINAM, 1997). The explanation in terms of religious-secular competition is as follows. In African countries, either secular, biomedical institutions are often lacking or the appropriate treatments are not affordable (UKAH, 2008). In such a situation, suppliers of religious healing, with their low production costs, have an immense advantage. In post-industrial societies, on the other hand, a high-quality biomedicine, supplemented with a general insurance system is in place. These secular options thus tend to displace the religious-magical alternatives and keep new upstart healing offers in a marginal place. This mechanism is in fact sometimes acknowledged by actors in the field themselves. In his fieldwork on Pentecostal healing in Switzerland, STOLZ (2011) found several Pentecostals remarking on the fact that there were more spectacular healings in African countries than in Switzerland, and that they believed this had to do with the fact that Swiss society was too rich and biomedicine too easily available, thus weakening faith. As one Pentecostal interviewee remarked: "We have a health system that is so developed [...] if we have a headache, we have the reflex of taking a pill or going to the 
hospital, while in regions where the health system is not so developed, you will probably see more healings [...] we are probably less open.” (Sara)

And another Pentecostal said: "When my daughter is ill, I ask her if she first wants to pray - but she says, no, I have my doctor, and then she goes to the doctor." (Claire-Lise)

\subsection{Religious socialization in Switzerland}

A mixed methods study on religion in Switzerland showed that in the 1960s, a collapse of the regulation of demand (decay of religious norms), an extreme expansion of secular options, and a strong increase of individual resources led to a "religious crisis" (Stolz et al., 2016). Individuals found themselves in a situation in which they no longer had to appear religious, and they had many attractive secular options and the necessary income to choose these options. This led to a new form of religious/secular socialization. Whereas older $(60+)$ respondents explained that their religious socialization (before the 1960s) was a matter of course, non-compliance being strongly sanctioned, younger respondents said that their religious socialization was optional. Parents after the 1960s believed that religious socialization was not strictly necessary and judged its usefulness in comparison with other possible uses of their children's time. They also thought that their children should ultimately choose themselves if they wanted to engage in religion. Quite often, they found that their children preferred to do other things (sports, dance etc.) instead of religious practice.

\subsection{From church attendance to shopping in the U.S.}

One of the most interesting examples of religious-secular competition is described in the study by Gruber and Huberman (2008, p. 58). These authors draw on the fact that in 16 US federal states, so-called "blue laws" were abolished at different times between 1955 and 1985. "Blue laws" prohibited, in the corresponding states, working and selling on Sundays. The authors found that the abolition of the laws (and, consequently, the beginning of Sunday work and sales) among Catholics and Protestants led to a significant decline in the incidence of church attendance in the respective U.S. states. Instead of entering the churches, apparently, more and more people moved into the consumption temples. Interestingly, the abolition of the blue laws did not lead 
to a complete exit from members who went to church irregularly in the first place, but above all to a reduction of attendance of regular church-goers. The authors comment: "The repeal of these laws in cities and states substantially increases the opportunity cost of religious attendance by offering alternatives for work, leisure, and consumption" (GRUBER; HUNGERMAN, 2008, p. 832).

\subsection{The rise and fall of female monasteries in the Western world}

The next example has been presented by Ebaugh (EBAUGH, 1993; EBAUGH, Lorence, \& Saltzman Chafetz, 1996) on the attractiveness of women's monasteries. Ebaugh shows that, from the mid-twentieth century onwards, the numbers of young women choosing to become nuns in the U.S. have been declining. She can also prove that female orders are rapidly shrinking in modernized regions of the world, while they are growing in the rest of the world. The explanation may be found, again, in a religioussecular competition: In the nineteenth century and early twentieth century, the career as a nun was relatively attractive in Western countries such as the U.S., since orders provided an avenue of social mobility for Catholic girls who did not want to become housewives and mothers. In fact, for many women, there were no other opportunities to obtain higher education and higher professional positions (EBAUGH et al. 1996, p. 174). These advantages disappeared when the general labour market was opened for women in the 1960s. In poorer regions of the world, however, the comparative advantages of becoming a nun are still present. Ebaugh (1996, p. 174) writes:

Throughout the nineteenth and early twentieth centuries, religious orders provided an avenue of social mobility for Catholic girls who, like most women in our society, had little or no opportunity for advanced educations and careers. The one exception was Catholic sisters, who tended to have more education than did laywomen at the time, and who had careers as teachers or nurses. Joining a convent, therefore, not only provided opportunities for young Catholic women but also brought status to the family blessed with having a daughter called to the convent.

\subsection{The late secularization of Ireland}

Another example concerns the late secularization of Ireland. In contrast to other Western European countries, Ireland has shown extremely high 
aggregate religiosity over decades. As Hirschle (2010) shows, the decline in religious practice between 1989 and 2005 coincides precisely with extreme economic growth. Hirschle interprets this fact in the sense of a religioussecular competition theory. Economic growth has strengthened individual purchasing power and increased consumption. This has led to the construction of a nonreligious symbolic world. Hirschle (2010, p. 9) explains: “[...] the consumption opportunities that accompanied economic growth in Ireland redirected the population's social behavioural patterns from religious to consumption-related routine activities [...]."

\subsection{The rise of megachurches in the U.S.}

A last example deals with the astounding fact that in the U.S., since the 1970s, the number of people concentrated in the very largest churches, the socalled megachurches, has consistently risen (CHAVES, 2006). This finding is true for denominations for which data is available. After reviewing various explanations that do not seem to work, Chaves (2006, p. 342) concludes that: " $[T]$ he increased concentration of people in the very largest churches is caused in part by rising costs that make it more and more difficult to run a church at a customary level of programming and quality."

We find this explanation plausible, but would like to add that this is basically a religious-secular competition explanation. In our view, it is the pressure of secular competition that leads churches to grow into megachurches. As customers expect higher quality in all areas, additional costs are incurred, which can only be absorbed by larger structures with high numbers of members and visitors. It is only thus that churches can afford high-quality choirs, sound systems, buildings etc., which seem competitive relative to what individuals usually expect in the secular domain.

\section{Discussion}

In this article, we have presented some basic elements of a theory of religious-secular competition on the individual level. We have argued that individuals in many societies can choose between religious and secular options, creating competition between religious and secular institutions. Bringing together insights from a wide range of disciplines, we have tried to 
show that religious and secular competition may help to explain a number of completely different phenomena.

Instead of summarizing the argument, let us briefly look at the structure of the explanations used in our examples. In the explanations of religioussecular competition theory, it is changes or differences either in innovations, regulations, or resource distributions that influence the competition game as well as family and individual actions and thereby the explananda. In the religious healing example, it is a difference of the level of biomedical standards (innovations) and available resources in the two contexts (European and African countries) that creates the different attractiveness of the explanandum attractiveness of religious healing. In the example of the abolishing of blue laws, it is a norm change that creates the explanandum "lower aggregated attendance of religious services". In the religious socialization example, it is a combination of innovations (new secular leisure options), norm change (fewer norms proscribing religion) and resource change (economic boom) that creates a drop and change in religious socialization in Switzerland. In the megachurch example, it is secular innovations (secular leisure options, shows, music etc.) that leads religious actors to innovate by creating megachurches to reach a comparable standard of quality.

The most important objection to the theory of religious-secular competition we have encountered so far is that it is nothing but secularization theory. And it is true that, just as in secularization theory, we think that a general trend towards technical and societal innovations will in the long run diminish the interest in religion in societies.

However, there are three points that seem to be treated more satisfactorily by the theory of religious-secular competition. First, agency is better addressed. In most versions of secularization theory, the explanans (differentiation, rationalization, societalization) and the explanandum (secularization) are processes that are difficult to untangle conceptually and that give no clear place to individual and collective actors. In the theory of religious-secular competition, individual and collective actors react either by choosing between secular and religious options (competition type 1) or by trying to change the rules of the game (competition type 2). Second, both secularizing and resacralizing phenomena can be satisfactorily addressed with the theory of 
religious-secular competition. Secularization theory has been rightly criticized as able to describe and explain only a diminishing of religion (and framing resacralization as anomalies). The theory of religious secular competition, on the other hand, as the examples have shown, describes and explains both up- and downswings of religion. Upswings are possible because of religious innovations, or rule- and resource changes that favour religious competitors. Third, it is applicable to different levels of the social. While secularization theory is a macro theory that is applicable in useful ways only to whole societies, this theory can be easily applied to different levels of the social (such as interactions, organizations, milieus, societies).

To become a successful paradigm, the theory of religious-secular competition must not only point to examples that may be recast in the light of the competition approach. It must also show that it is capable of guiding empirical research. This is where much work remains to be done. We welcome studies that try to put the ideas put forward in this article to the test.

\section{References}

ABBOTT, A. The System of Professions. An Essay on the Division of Expert Labor. Chicago: The University of Chicago Press, 1988.

ALTERMATT, U. Konfession, Nation und Rom. Metamorphosen im schweizerischen und europäischen Katholizismus des 19. und 20. Jahrhunderts. Frauenfeld: Huber, 2009.

ANYINAM, C. A. The Role of Female Spiritualists in Africa. Persistence with Change. Canadian Women Studies/Les Cahiers De La Femme, v. 17, n. 1, p. 103-106, 1997.

AZZI, C.; EHRENBERG, R. Household Allocation of Time and Church Attendance. Journal of Political Economy, v. 83, n. 1, p. 27-56, 1975.

BERGER, P. L. [1967]. The Sacred Canopy: Elements of a Sociological Theory of Religion. New York: Anchor Books, 1990.

BOUDON, R. The Logic of Sociological Explanation. Suffolk: Penguin Education, 1974. Beyond Rational Choice Theory. Annual Review of Sociology, v. 29, p. 1-21, 2003. BOURDIEU, P. Le sens pratique. Paris: Minuit, 1980.

. La dissolution du religieux. In: DERS (Ed.). Choses dites. Paris: Editions de Minuit, 1987. p. 117-123. 
CARON, F. L'innovation. In: GILOMEN, H.-J.; R. JAUN, J; MÜLLER, M.; VEYRASSAT, B. (Ed.). Innovationen. Voraussetzungen und Folgen - Antriebskräfte und Widerständ. Zürich: Chronos, 2001. p. 19-31.

CHAVES, M. Religious congregations and welfare reform: Who will take advantage of charitable choice?. American Sociological Review, v. 64, p. 836-846, 1999.

All Creatures Great and Small: Megachurches in Context. Review of Religious Research, v. 47, p. 329-346, 2006.

CONZE, W.; KOCKA, J. (Ed.). Bildungsbürgertum im 19. Jahrhundert. Teil I. Bildungssystem und Professionalisierung in internationalen Vergleichen. Stuttgart: KlettCotta, 1985.

DOW, J. Universal aspects of symbolic healing: A theoretical synthesis. American Anthropologist, New Series 88:56-69, 1986.

DARWIN, C. [1859]. The Origin of Species. London: Penguin Books, 1985.

EBAUGH, H. R. The Growth and Decline of Catholic Religious Orders of Women Worldwide: The Impact of Women's Opportunity Structures. Journal for the scientific study of religion, v. 32, n. 1, p. 68-75, 1993.

; LORENCE, J.; SALTZMAN CHAFETZ, J. The Growth and Decline of the Population of Catholic Nuns Cross-Nationally, 1960-1990: A Case of Secularization as Social Structural Change. Journal for the scientific study of religion, v. 35, n. 2, p. 171-183, 1996. EDWARDS, M. U. Printing, Propaganda and Martin Luther. Berkeley, CA: University of California Press, 1994.

EINSTEIN, M. Brands of Faith. Marketing religion in a commercial age. London: Routledge, 2008.

ESSER, H. Soziologie. Spezielle Grundlagen. Band 1: Situationslogik und Handeln. Frankfurt: Campus, 1999.

FOX, J. The Secular-Religious Competition Perspective. In: HERRINGTON, L. M.; MCKAY, A; HAYNES, J. (Ed.). Nations under God: The Geopolitics of Faith in the TwentyFirst Century. Bristol: E-International Relations Publishing, 2015. p. 80-87.

FROESE, P.; PFAFF, S. Explaining a Religious Anomaly: A Historical Analysis of Secularization in Eastern Germany. Journal for the scientific study of religion, v. 44, n. 4, p. 397-422, 2005. 
GILL, A.; LUNDSGAARDE, E. State Welfare Spending and Religiosity: A Cross-National Analysis. Rationality \& Society, v. 16, n. 4, p. 399-436, 2004.

GRUBER, J.; HUNGERMAN, D. M. The Church vs. the Mall: What Happens When Religion Faces Increased Secular Competition?. Quarterly Journal of Economics, p. 831862, may 2008.

HECHTER, M. Principles of Group Solidarity. Berkeley: University of California Press, 1987.

HEDSTRÖM, P. Dissecting the Social. On the Principles of Analytical Sociology. Cambridge: Cambridge University Press, 2005.

HIRSCHLE, J. From Religious to Consumption-Related Routine Acetivities? Analyzing Ireland's Economic Boom and the Decline in Church Attendance. Journal for the scientific study of religion, v. 49, n. 4, p. 673-687, 2010.

HUNGERMAN, D. M. Rethinking Religious Competition. Working Paper, p. 1-26, 2010. Disponivel in: <http://66.223.50.234/asrec/archive/papers/Hungerman $\% 20-\% 20$ Rethinking\%20Religious\%20Competition\%20-\%20ASREC09.pdf>. Access in: 10 june 2017.

IANNACCONE, L. R. A Formal Model of Church and Sect. American Journal of Sociology, v. 94 (Supplement: Organizations and Institutions: Sociological and Economic Approaches to the Analysis of Social Structure), p. S241-S268, 1988.

Introduction to the Economics of Religion. Journal of Economic Literature, v. 36, n. 3, p. 1465-1495, 1998.

KAUFMANN, F.-X. Herausforderungen des Sozialstaates. Frankfurt am Main: Suhrkamp, 1997.

KIEFER, B. La guérison dans la médecine scientifique. In Quêtes de santé. Entre soins médicaux et guérisons spirituelles, Hrsg. Nicole Gauthier Durisch, Ilario Rossi und Jörg Stolz, 31-36. Genève: Labor et Fides, 2007.KNOBLAUCH, H. Spirituality and Popular Religion in Europe. Social Compass, v. 55, n. 2, p. 140-153, 2008.

KNOBLAUCH, H. Populäre Religion. Auf dem Weg in eine spirituelle Gesellschaft. Frankfurt: Campus Verlag, 2009.

LAMBERT, Y. [1985]. Dieu change en Bretagne. La religion à Limerzel de 1900 à nos jours. Paris: Les Editions du Cerf, 2007. 
LUCKMANN, T. The Invisible Religion. New York: MacMillan, 1967.

MCLEOD, H. The Religious Crisis of the 1960s. Oxford: Oxford University Press, 2007.

MCMULLIN, S. The Secularization of Sunday: Real or Perceived Competition for Churches.

Review of Religious Research, v. 55, p. 43-59, 2013.

MERTON, R. K. On Sociological Theories of the Middle Range. In: DERS (Ed.). Social Theory and Social Structure. New York: The Free Press, 1968. p. 39-72.

MOTTNER, S. Marketing and religion. In: WYMER, W; SARGEANT, A. (Ed.). The Routledge Companion to Nonprofit Marketing, 2007. p. 92-107.

MÜLLER, M.; VEYRASSAT, B. Einleitung. Was sind Innovationen?. In: GILOMEN, H.J.; R. JAUN, J; MÜLLER, M.; VEYRASSAT, B. (Ed.). Innovationen. Voraussetzungen und Folgen- Antriebskräfte und Widerstände. Zürich: Chronos, 2001. p. 9-13.

PARSONS, T. [1951]. The Social System. Kent: Mackays of Chatham PLC, 1991.

PEPPER, M.; STERLAND, S.; POWELL, R. Methodological overview of the study of wellbeing through the National Church Life Survey. Mental Health, Religion \& Culture, v. 18 , n. 1 , p. $8-19,2015$.

POLLACK, D. Was ist Religion? Probleme der Definition. Zeitschrift für Religionswissenschaft, $v$. 8, p. 11-43, 1995.

.; ROSTA, G. Religion in der Moderne. Ein internationaler Vergleich. Frankfurt; New York: Campus, 2015.

PORTIER, P.; VEUILLE, M.; WILLAIME, J.-P. (Ed.). Théorie de l'évolution et religions. Paris: Riveneuve éditions, 2011.

RAUlFF, U. (2015): Das letzte Jahrhundert der Pferde. Geschichte einer Trennung. München: C. H. Beck.RÖMER, T. La formation du pentateuque: histoire de la recherche. Genève: Labor et Fides, 2004.

RUSSELL, A. The Clerical Profession. London: SPCK, 1980.

SCHULZ, C. Kirchenmitgliedschaft und Glaubensüberzeugung in der Perspektive der Gruppendiskussionen. In: HUBER, W.; FRIEDRICH, J.; STEINACKER, P. (Ed.). Kirche in der Vielfalt der Lebensbezüge. Die vierte EKD Erhebung über Kirchenmitgliedschaft. Gütersloh: Gütersloher Verlagshaus, 2006. p. 111-128.

SCHWEITZER, A. Geschichte der Leben-Jesu-Forschung. Band 1. Tübingen: J. C. B. Mohr, 1966. 
SEARLE, J. R. The Construction of Social Reality. New York: The Free Press, 1995.

SIMON, H. A. Reason in Human Affairs. Stanford, California: Stanford University Press, 1983.

STARK, R.; FINKE, R. Acts of Faith. Explaining the Human Side of Religion. Berkeley: University of California Press, 2000.

.; IANNACCONE, L. R. A Supply-Side Reinterpretation of the "Secularization of Europe". Journal for the scientific study of religion, v. 33, n. 3, p. 230-252, 1994.

STOLZ, J. All Things Are Possible. Towards a Sociological Explanation of Pentecostal Miracles and Healings. Sociology of Religion, v. 72 , n. 4, p. 456-482, 2011.

Entwurf einer Theorie religiös-säkularer Konkurrenz. Kölner Zeitschrift für Soziologie und Sozialpsychologie, v. 65 (Sonderheft 1), p. 25-49, 2013.

.; CHAVES, M. Does Disestablishment Lead to Religious Vitality? The Case of Switzerland. British Journal of Sociology, v. 39, n. 143, p. 1-24, 2017.

.; KÖNEMANN, J.; SCHNEUWLY PURDIE, M., ENGLBERGER, T.; KRÜGGELER, M. (Un)Believing in modern society. Religion, spirituality, and religioussecular competition. London: Routledge, 2016.

.; USUNIER, J.-C. Religions as Brands. New Perspectives on the Marketization of Religion and Spirituality. In: STOLZ, J.; USUNIER, J.-C. (Ed.). Religions as Brands. New Perspectives on the Marketization of Religion and Spirituality. London: Ashgate, 2013. p. 3-26.

THEISSEN, G. Der historische Jesus. Ein Lehrbuch, 3, Auflage. Göttingen: Vandenhock \& Ruprecht, 2001.

UKAH, A. Religion and Healing: A West African Perspective. Research Paper. BIGSAS Interdisciplinary Research Seminar, 5 june 2008. p. 1-168.

VOAS, D.; CHAVES, M. Is the United States a Counterexample to the Secularization Thesis?. American Journal of Sociology, v. 121, n. 5, p. 1517-1556, march 2016.

WALLIS, R.; BRUCE, S. Secularization: The Orthodox Model. In: BRUCE, S. (Ed.). The sociology of religion. Aldershot: Elgar, 1995. p. 693-715. 


\section{Elementos de uma teoria de competição religioso-secular}

\section{Resumo}

Este artigo apresenta elementos básicos de uma teoria da competição religioso-secular ao nível individual. A teoria argumenta que, em muitas sociedades, os indivíduos podem escolher entre opções seculares e religiosas, criando uma situação de competição entre instituições religiosas e seculares. A competição entre fornecedores religiosos e seculares é influenciada por três fatores contextuais importantes: inovação, regulação e recursos. Oferecemos seis exemplos de estudos empíricos que demonstram que a teoria da competição religioso-secular explica fenômenos contrastantes como a diferença no sucesso da cura pela fé em países africanos e europeus, a mudança e diminuição da socialização religiosa na Suíça, as variações da frequência às igrejas nos EUA, a variação na atratividade dos mosteiros, a secularização tardia da Irlanda ou o sucesso das megaigrejas desde a década de 1970.

Palavras-chave: Competição religioso-secular. Secularização. Mudança religiosa.

Recebido em: 02/03/2017. Aprovado em: 06/06/2017. 